Georgetown University Law Center

Scholarship @ GEORGETOWN LAW

2010

\title{
Honor Killings and the Construction of Gender in Arab Societies
}

Lama Abu-Odeh

Georgetown University Law Center, la34@law.georgetown.edu

This paper can be downloaded free of charge from:

https://scholarship.law.georgetown.edu/facpub/1631

58 Am. J. Comp. L. 911-952 (2010)

This open-access article is brought to you by the Georgetown Law Library. Posted with permission of the author. Follow this and additional works at: https://scholarship.law.georgetown.edu/facpub

Part of the International Humanitarian Law Commons, Law and Gender Commons, and the Law and Society $\underline{\text { Commons }}$ 


\section{LAMA ABU ODEH*}

\section{Honor Killings and the Construction of Gender in Arab Societies $\dagger$}

This Article discusses the regulation and adjudication of honor killings in the Arab world and traces the distributive and disciplinary impact of such regulation/adjudication on Arab men and Arab women's sexuality. In the afterword, the Article outlines the transformative effect of Islamicization of culture in the Arab world in the past twenty years on the practice of honor and killings committed in its name.

\section{INTRODUCTION}

This Article is a discussion of honor killings in the Arab world. A paradigmatic example would be the killing of a woman by her father or brother for engaging in, or being suspected of engaging in, sexual practices before or outside of marriage. On a simple and immediate level, this article calls for an end to these killings for their obvious cruelty. All Arab laws or judicial practices that legitimize or sanction these killings should be abolished.

On a more complicated level, this article attempts to identify the role that these killings play in the production and reproduction of gender relations in contemporary Arab life. It contends that these relations are the outcome of a complex triangular interaction between social violence (the honor killing itself); state violence (the attempt to regulate this killing by making it a crime of honor), and; the response by contemporary men and women to the balance between these two types of violence.

The argument of this article is that in the past, honor killings were largely unregulated, practiced as a means of controlling the violators, punishing them for vice and deviancy from prescribed sexual rules. Despite the fact that such killings continue to this day, the article argues that their social function has changed.

* Professor of Law, Georgetown University Law Center, LL.B., University of Jordan; LL.M., University of Bristol, UK; MA Philosophy, University of York, York, UK; S.J.D., Harvard Law School.

† DOI 10.5131/ajcl.2010.0007. 
The intervention of the Arab nationalist elite in the social field, by desegregating gendered social space, rendered the concept of sexual honor ambiguous. Through codification, they aimed to "modernize" a traditional practice, honor killing, by limiting its practice, by penalizing some violators. The mode of regulation they adopted could be seen as a strategy to contain the practice.

When adjudicating these killings, the Arab judiciary tended to perform a double function: contain the practice of honor killings whilst co-opting the emergence of subversive sexual types and practices among men and women.

The mushrooming of diverse sexual types and practices could in turn be seen as a response to the interaction between social violence, (the killing itself) and its regulation (the crime of honor).

The end picture is complicated, with the killings being a response to the new sexual practices, their contemporary function; the state regulation and judicial practice being a response to the violence and the sexual practices; the resistant sexual types and practices being a response to the balance between the two types of violence, social and official.

But this is not all. While the regulation of the killings relies on difference-splitting between the concept of passion and that of honor, and while adjudication of the crime reconstructs the split on new terms by moving it further in the honor direction, the split-upon-split for the purpose of containing subversive sexualities ultimately distributes the surplus of tolerated violence along class lines.

Reports of the crime reveal that poor women killed by their male relatives are more frequently the victims of honor killings. This leaves us with the unavoidable conclusion that nationalist honor is upheld by dividing women into sexual rebels (the well-off) on the one hand, and possible victims of killing (the poor) on the other, and in a parallel fashion, dividing men into possible killers (the poor) on the one hand, and disciplinarian, beneficiaries-of-the-killing-of-the-poor (the well-off) on the other.

If indeed the demand to completely abolish honor killings by severely punishing their perpetrators is unrealistic, the article argues that these lenient treatement of crimes should be limited to those of passion. This is a viable move because the spectrum of codification of crimes of honor already existing within the Arab world has, within its parameters, the legal construct of a crime of passion (see the cases of Algeria and Egypt below). What seems to have prevented the full development of the concept of a crime of passion in these two respective countries is judicial practice that tends to use alternative legal means to reintroduce the idea of a crime of honor. 


\section{What is an Honor Killing?}

"Where were you, bitch?" Maria Isa snapped as her daughter, Tina, 16, entered the family apartment.

"Working," Tina shot back. Zein.

"We do not accept that you go to work," interrupted Tina's father,

"Why are you doing this to us?" asked Maria angrily.

"I am not doing anything to you," Tina bristled.

"You are a she-devil," hissed Zein, "and what about the boy who walked you home? He wants to sleep with you in bed, don't you have any shame? Don't you have a conscience? It's fornication."

With that her parents threatened to throw Tina out of the apartment; rebelliously she challenged them to do it.

"Listen, my dear daughter," her father finally replied, "Do you know that this is the last day? Tonight you're going to die?"

"Huh?" said Tina bewildered.

"Do you know that you are going to die tonight?"

Suddenly, realizing he was serious, Tina let out a long scream. Then there was a crash, and the girl's shrieks became muffled, as if someone were trying to cover her mouth. "Keep still, Tina," her father shouted.

"Mother, please help me," Tina cried.

"Shut up!" Her mother shouted.

"No! No!" Tina shrieked.

"Die! Die quickly!" Her father shouted.

Tina managed to scream again.

"Quiet, little one," her father said, stabbing her the last of six times.

"Die, my daughter, die!"1

\section{A. The Legal Codification of Honor Killings}

The locus of crimes of honor in the Jordanian Penal Code (no. 16, 1960 ) is Article 340. The first Article of three in a section entitled "Excuse in Murder" states:

He who catches his wife, or one of his female un-lawfuls committing adultery with another, and he kills, wounds, or

1. Joe Treen, Die, My Daughter, Die!, People WeekLy, Jan. 20, 1992, at 71 . On November 6, 1989, Zein Isa, an Arab immigrant in the United States, stabbed his daughter Tina to death "to defend his honour." We have a record of the events that took place the evening of Tina's death, because the FBI, unknown to the Isas, was bugging the apartment under the pretext that Zein was suspected of being a member of a "terrorist" organization. Unfortunately for Tina, no one was listening to the tape at the time of her death. 
injures one or both of them, is excused and benefits from an exemption from penalty.

He who catches his wife, or one of his female ascendants or descendants or sisters with another in an un-lawful bed, and he kills or wounds or injures one or both of them, benefits from a reduction of penalty.

Article 340 was its historical origin in two legal sources that are surprisingly harmonious when it comes to the issue of "honor killings." They are the Ottoman Penal Code of 1858 and the French Penal Code of $1810 .^{2}$

Article 324 of the French Penal Code ${ }^{3}$ reads:

Whoever catches his spouse, female ascendant, descendant or his sister red-handed in the act of adultery or in an illegitimate sexual encounter with another person and commits homicide or causes injury can benefit from an excuse of exemption.

The author of the homicide or injury can benefit from an excuse of reduction if he catches red-handed his spouse, female ascendant, descendant, or his sister in an "attitude equivoque."

Article 188 of the Ottoman Code reads:

He who catches his wife or any of his female un-lawfuls with another in a state of "ugly" adultery ${ }^{4}$ and then beats, injures, or kills one or both of them will be exempt from penalty. And he who catches his wife or one of his female un-lawfuls with another in an un-lawful bed and he beats, injures or kills one or both of them, will be excused.

A provision similar to Article 340 of the Jordanian Penal Code exists in almost every Arab Penal Code, as well as the Turkish Code, and many European Codes as well: Spanish, Portuguese and Italian

2. The Lebanese Penal Code no. 340 of 1943 is considered the most immediate historical source of the Jordanian Penal Code of 1960. See KAmEL SAID, THE GenERaL Principles of Crime in the Jordanian Penal Code (1981). The Lebanese Code itself has its historical origins in the Ottoman Penal Codes of $1840,1851,1858$, a series of codes promulgated in an effort to "modernize" the Ottoman empire. While the first two were primarily based on Islamic Law and local custom, the third was deeply influenced by the French Code of 1810 . See Mahmoud Nagib Husni, Treatise on the LEBANESE CODE (1968).

3. Emile Garçon, Code penal annoté 151 (Recueil Sirey 1951) (1901).

4. The word "adultery" in this context is a translation of the word zina which in Islamic law refers to illicit sexual relations between men and women whether they were married or not. 
(though abolished in 1979). The provision in the French Penal Code was not abolished until $1975 .{ }^{5}$

Arab Penal Codes, in regulating honor killings, differ on two issues. First, some Codes (Egypt, Tunisia, Libya, and Kuwait) limit the defense to situations of adultery, and they provide for a reduction of, not exemption from, punishment. Other Codes expand the defense to situations of the "un-lawful bed" (Jordan) or "attitude equivoque" (Syria, Lebanon) which receive a reduced sentence, while limiting the excuse of exemption to cases of adultery. The Iraqi Code is unique in that it covers both the situation of adultery and what it calls "her presence in one bed with her lover" but gives them both the same excuse, namely that of reduction to three years.

Second, Arab Penal Codes differ on who benefits from the excuse. The Syrian and Lebanese Codes adopt the French terminology (wife, female ascendants, descendants and sister) so that the husband, the son, the father and the brother benefit. The Jordanian Code grants these relatives a reduced sentence in the case of the unlawful bed, while providing exemption for a bigger list of beneficiaries through its use of the Ottoman expression, wife or female un-lawfuls in the case of "committing adultery." This expands the beneficiaries of the excuse to a considerable degree since a female un-lawful includes every woman that the man cannot marry either for blood, marriage (in-law) or nursing reasons (according to the Islamic Jurisprudential tradition), which makes the disparity between the first and second section of the article quite significant and almost mysterious. The Iraqi Code uses an expression similar to that of the first section of the Jordanian Article, "his wife or one of his female un-lawfuls," to cover both cases of adultery and "one bed." The Egyptian, Kuwaiti and Tunisian Codes include only the husband as beneficiary, while the Libyan Code expands the list to the husband, father and brother. The Algerian Code is unique in that it treats both husband and wife as beneficiaries of the excuse, which it limits to situations of adultery. ${ }^{6}$

Structurally speaking, the Codes seem to be distributed on a spectrum with two opposite poles. The first is best represented by the Algerian Code in which both husband and wife benefit from a reduction of penalty when s/he catches the other committing adultery. The other pole is best exemplified by the Jordanian Code which allows men to benefit from both a reduction and an exemption of penalty if they catch one of their female un-lawfuls committing adultery or in an un-lawful bed with her lover. The difference between these two

5. (Abolished by Article 17, Law no. 617/75 issued on Nov. 7,1975) . See LAurE MughayzIL, AL-MAR'A FI AL-RASHRI' AL-LUBNANI (1985).

6. Lebanese Penal Code, art. 562; Syrian Penal Code, art. 548; Egyptian Penal Code, art. 237; Kuwaiti Penal Code, art. 153; Iraqi Penal Code, art. 409; Algerian Penal Code, art. 279; Libyan Penal Code, art. 375; Tunisian Penal Code, art. 207. 
ends map roughly onto the difference between the idea of a crime of passion, the former, and a crime of honor, the latter.

Why does the Egyptian Code choose the husband as beneficiary, while the Libyan one chooses father, brother, and husband? What inspires these choices? Clearly every choice is an act of "picking": adopting some elements, dropping others, a simultaneous act of inclusion and exclusion. We can see these choices on our spectrum running from the idea of pure honor on one end to pure passion on the other. We come to realize that every Code situated in between these two poles is a form of compromise between the two ideas of honor and passion, each in its pure form. This compromise reflects an attempt by each national legislature to strike a balance between two conflicting ideas, pulling in opposite directions.

Thus, in order to understand the variations in the Codes we have to come to grips with the ideas of honor and passion. We will take up the idea of honor first, by looking at it from an anthropological perspective. The purpose of the discussion is to understand the honor/ shame social system that produces the honor killing. The Codes can be seen as a legal intervention in this universe of honor killings. Their intervention takes the form of legitimizing certain killings and de-legitimizing others. For instance, all Codes seem to make the radical move of de-legitimizing the paradigmatic model of honor killings: the killing of a woman by her father or brother when she is discovered not to be a virgin on her wedding night. None of these Codes grants an excuse, exemption or penalty reduction in such a case. When we understand the prominence of this kind of killing in an honor-dominated world, we begin to get a sense of the seriousness of the Codes' intervention.

The following section will consider honor relations in what I will call the traditional text: a description of a society in which honor relations prevail with clarity and predictability. In this society, an ideal one by definition (perhaps even idealized), the transgression of boundaries immediately results in a killing of honor. Having identified what this society might look like, I will, by way of contrast, reconstruct another that is based on passion (equally ideal/ized). The point of the exercise is to understand the two conflicting ideals between which each Code tries to strike some balance.

\section{B. An Anthropological Discussion of Honor in Arab Societies}

1. Virginity as the Regulatory Practice of Gender

Writings about the importance of women's virginity before marriage in the Arab world are not lacking. ${ }^{7}$ Arab women, according to

7. See Nawal El SaAdawi, The Hidden Face of Eve, (Sherif Hetata ed. \& trans., Zed Press 1980) (1977); Lila Abu-Lughod, Velled Sentiments: Honor AND 
the ideal model, are expected to abstain from any kind of sexual practice before they get married. The hymen, in this context, becomes the socio-physical sign that signifies virginity and gives the woman a stamp of respectability and virtue. The wedding night, therefore, has phenomenal importance for Arab women, since it is that crucial moment when society is about to make a judgment on their propriety. ${ }^{8}$ Some honor crimes are known to occur precisely when a woman who fails to bleed, as a result of penetration breaking her hymen, is taken to have failed the social test. In this classic scenario, she is "taken back" by the groom and his family to her own family, who in turn kill her for having shamed them. Only her bleeding in death can erase the shame brought about by her failure to bleed in sex on her wedding night.

The discourse on gender and the discourse on virginity in Arab culture overlap so broadly that they are hardly distinguishable. To be an Arab woman is to engage in daily practices, an important part of which is to be a virgin. A heterosexuality that is honor/shame-based such as the Arab one, demands, under the sanction of social penalty, that the performance of femaleness stylizes the body that is called female as virginal. The hymen, in this context, acquires the double function of being both a mark of virginity and of delineating the boundaries of the body that is called female. This, indeed, is what distinguishes it from the male body, since the latter can bear no such mark of virginity.

It is almost impossible to list the daily practices that are necessary for the construction of the virgin/female body in Arab culture. One way of doing it would be to look at it in a "regressive" fashion: women need to abstain from any sexual activity before marriage, and from any act that might lead to sexual activity. The further back we go, the fuzzier the list of actions involved. Every prohibition she complies with constructs her simultaneously as female and as virginal. "If you want me to count the dos and don'ts, the list would go on forever. It seems that everything is aib (shame) for girls."

The function of these prohibitive demands is not only the preservation of actual virginity but the production of the public effect of

Poetry in Bedouin Society (1986); M.E. Combs-Schilling, Sacred Performances: Islam, Sexuality, and Sacrifice (1989); David Gilmore, Am. Anthropological Ass'n, Honor and Shame and the Unity of the Mediterranean (1987).

8. If they find blood on the bride's sarwal (drawers) they make a quivering noise and dance in the room, the bride's sister dances in the room with the trousers on her head. It is then hung up in the yard so that all people should see the marks of virginity. Should there be no such blood, the bridegroom's family would exclaim, "go away from me, you bitch;" and the bride's father, or in his absence, her brother, would shoot her dead in the room or in the yard, besides which, all the money and presents given would be returned.

ComBs-Schilling, supra note 7, at 208.

9. Sana al-Khayyat, Honour and Shame: Women in Modern Iraq 33 (1990). 
virginity. In other words, the physical attachment of the hymen to the body needs to be evidenced and publicized, i.e., signified, through an elaborate performance for the benefit of the social audience. ${ }^{10}$ Thus, the hymen becomes displaced from its biological vessel, the vagina, onto the body as a whole, "hymenizing" it, and producing it as a body called female. But then it is displaced again onto the social space where the female body is allowed to move and be, encircling it as a social hymen that delimits its borders. Female gender performance covers all three meanings together. Each of the above borders, the vaginal, the bodily, and the social, is enforced through a set of regulations and prohibitions that the woman is not supposed to violate.

I am always being told, you can't smoke because you are an Arab woman, or you can't dress that way because you are an Arab woman, and if I sit in a café with a male friend people immediately begin to gossip about me. ${ }^{11}$

A crime of honor can occur when any of the above borders is crossed. Killing a woman because she fails to bleed on her wedding night is one possible scenario for an honor killing. But a failure to perform honor/shame-based heterosexuality can be evidenced by far more minor miscues. In certain rural localities, a woman might suffer the violence of honor if she is spotted conversing with a man behind a fence or, in lower-class urban neighborhoods, if she is seen leaving the car of a strange man. In both instances, the woman is seen as having jeopardized not her vaginal hymen but her physical and social one. She moved with a body and in a space where she was not supposed to be. ${ }^{12}$

Sanctions upholding this kind of heterosexuality are designed to preempt the honor killing and prevent its occurrence. Through an elaborate system of commands and prohibitions, girls learn their gender performance at a very young age. The culture guards itself

10. I borrow my construction of virginity as performance from the idea that gender itself is performance. Judith Butler, Gender Trouble: Feminism and the SUBVERSION OF IDENTITY (1990).

11. Interview with a Palestinian woman living in Israel, Kol HaIR, June 28, 1991. The performance of public virginity through a stylized body and space also covers the woman's speech. Not only is the woman not supposed to smoke in public or wear a short dress (acts associated with "whorish" behavior), but she is also expected not to engage in talk that transgresses the code of virginity. Talk about sex in general (except between women in their own private space) is considered to be such a transgression. A woman who talks, hints, insinuates, or jokes about sex in public is seen as having committed a disgraceful act that often invites violent reactions from males in her family. Flirtatious behavior on the part of the woman is perceived similarly.

12. Treen, supra note 1 , at 71 . Zein Isa killed his daughter Tina simply because she had been walked home by a male friend a number of times before the night of her death. Isa was an American immigrant who had originally come from a Palestinian village where he had grown up and lived most of his life. 
against possible violations by devising sanctions less violent than death that are meant to preclude it. These sanctions include the threat of physical punishment, spatial entrapment through segregation of gender spaces, and the active mobilization of the institutions of social gossip and reputation. "Because you are a girl, and people will talk if you do this," is the rhetorical means by which Arab women come to acquire their gendered subjectivity.

From the time we were very small, my brother and I shared the same friends, nearly all boys, most of whom were the children of our neighbors. The boys remained my companions until I grew up-that is until I was eleven when suddenly I was required to restrict myself to the company of girls and women ... Being separated from the companions of my childhood was a painful experience. ${ }^{13}$

Marriage ends the performance of biological virginity. Since the majority of women get married, and most at a relatively young age (especially if they are poor), women are released early in their lives from the burden of the performance of biological virginity. This, however, leaves intact the social demand for performance of bodily and social virginity.

\section{What it is to be an Arab Man}

The man who kills his sister to defend his honor epitomizes in a dramatic way, through his act, the performance of his gender. Virginity, in its expanded sense (the vaginal, bodily, and social) is also the locus of his gender in that he needs to guard, supervise, and defend against incursions of his women's virginity. To be an Arab man is to engage in daily practices, an important part of which is to assure the virginity of the unmarried women in your family. In Arab culture, a man is that person whose sister's virginity is a social question for him.

Male performance is equally sanctioned by penalties. If a man doesn't intervene by killing his sister or wife once she has shamed him, he suffers a loss of his gender: he is no longer a man (therefore, castrated, a "bottom," a woman). His performance has suffered a serious failure. ${ }^{14}$

13. Margot Badran, Opening the Gates: A Century of Arab Feminist Writing 4 (Miriam Cooke ed., 1990).

14. When a man is shamed through an erotic defeat or an equivalent social submission he is symbolically emasculated: his physical integrity is dissolved and he succumbs to the ever-present danger of sexual reversal, or feminization. In a sense, he surrenders his own masculine identity and becomes a woman who is victimized and penetrated.

Id. at 6. 
But even before he has to intervene in a dramatic way, he gives license to, supervises, disciplines "his" women's behavior so that he experiences his gender rhetorically through statements like, "I will not have my sister do this," or more magnanimously, "I don't mind if my wife does that." 15 Here's how one male university graduate put it:

"I wanted to propose to a neighbor of mine of whom I was very fond. But I changed my mind when I saw a photo of her and a male neighbor. I wouldn't permit my sister to do this, and I would expect my fiancée to act in a similar way."16

As one might expect, inasmuch as the man is the censor of "his" own women, he is also censored in relation to other men's women. As he is busy cementing the blocks of "his" women's hymens, in the expanded sense, he is also, simultaneously, bumping into similar walls elsewhere, those cemented by other men. As women have internalized the censoring look of men, so have men internalized the censoring look of other men. This has the effect of stylizing the space that men, in general, occupy.

More complicated yet, men make implicit deals with other men that have the double function of, on the one hand, nurturing their brotherly bonds, and, on the other, creating a certain camaraderie between them in their hunt for other women. The male bond is nurtured when men promise each other, through their behavior, that their friends' women are as haram (forbidden) to them as their own women are to their friends. Men make deals with each other that they will not try to sneak inside the walls cemented by their friends around their own women. Having made those implicit deals, men are allowed to feel trust for one another that is then exploited for the purposes of trying to sneak behind the walls cemented by other men, i.e., those outside the circle of this particular camaraderie. This would include men who are not their friends, relatives, neighbors, or countrymen, depending on the social context.

What this means is that Arab men are virgins by default. The culture does not actively seek, stress or demand their virginity. However, it makes it very hard for them not to be virgins, given its demand for women's virginity. Nothing befalls a man if he is not a virgin, and yet most men find themselves to be so. If they are not, it is only erratically and infrequently, and as a result of a constant and difficult negotiation within the economy of space in which they live.

15. Sawsan el-Messiri, Bint el-Balad: Self Images of Traditional Urban Women in Cairo, in WOMEN IN THE MusLIM WORLD (Lois Beck \& Nikkie Keddie eds., 1978).

16. Id. at 721 . 


\section{Contrasting Honor with Passion}

We have seen how many Arab Codes reconstruct a moral universe based on honor by showing sympathy for the father, brother, husband: allowing them exemptions from, or reductions in, penalty when they kill to defend their honor. They reflect the social intolerance for any female sexual behavior, seeing it as deeply threatening to men's masculinity.

However, the Codes, in fact, fall short of legitimizing honor killings as they would occur in an idealized honor-based society. They do this in two ways.

First, they exclude from excuse, whether that of exemption or reduction, two types of honor killings that typify an honor society: the killing of a woman because she is found not to be a virgin on her wedding night, and the killing of an unmarried woman when she is discovered to be pregnant. Not a single Arab Code excuses what would have been conventional honor killings in this social universe. This exclusion is a very radical move by the codifiers. It attempts to strike at the heart of the honor society by barring these cruel acts. ${ }^{17}$

Second, they construct the excuse in ways that deviate from the traditional honor killing in three ways. As we have seen above, all Codes require "surprise," flagrante delicto, and the immediate killing of the woman. Presumably, in a purely honor-dominated world, none of these considerations would apply. Suppose a woman commits a dishonorable act that is reported through gossip to her male family members, who then meet to deliberate and then decide to kill her. Socially this is a crime of honor, but the Codes punish the killers. The bifurcation between reduction and exemption in the Codes, for unlawful bed (attitude equivoque) and adultery respectively, is foreign to the traditional world of honor. In that world, both cases would be justified and killers exempt from penalty. Finally, the parties made beneficiaries in the Codes do not include all those who would be socially allowed to commit an honor killing in a conventional honor society. If we take the "un-lawfuls" as signaling the paradigmatic model of the beneficiaries in an honor-based society, then we find that all Codes, without exception, exclude some relatives; this includes even the Jordanian Code, which excludes them from the case of "un-lawful bed," using instead the expression of ascendants and descendants. The Algerian Code includes the wife as beneficiary, which would never be permitted in the traditional honor world.

17. I have been told by a Criminal District Attorney in Amman that Jordanian police instruct gynecologists to inform them if the family of a woman wants to verify whether she is a virgin. The police in such cases try to marry the woman to the man who she claims has caused her loss of virginity. Similarly, Jordanian gynecologists have told me, on conditions of anonymity, that they perform operations called "hymenorrophy," reconstructing a broken hymen. Like the Codes, these practices seek to delegitimize traditional honor killings. 
The question arises how to explain these departures from the idea of honor in conventional society in the Arab Codes? What is the reason for the legislative exercise of partial de-legitimization? There appears to be, as indicated above, a rival conception also at work in the Codes, which influences in its own right the question of when it is legitimate for men to kill women. This rival conception is that of passion.

The idea of passion, in its pure form, involves a private relationship between a man and a woman, as opposed to a collective one that involves several men related to the woman deeply engaged in defending the public image of their masculinity. In the model of passion, female sexuality is not fetishized as the locus of reputation, but seen more as a libidinal goal and the locus of complicated human emotions. Passion reduces the relationship to two people who are sexually involved with each other (especially man and wife), for whom the sexual misbehavior of one is an assault on the other's feelings, not his public reputation. The passion model excludes men who are not or cannot be sexually involved with the woman (father, brother, son) and emphasizes passionate jealousy, not castrated masculinity. We have seen how the Egyptian and Algerian Codes reflect this kind of relationship: it is only the injured husband (or wife in the Algerian case) who benefits from an excuse and only that of a reduction in penalty when they catch the other in flagrante delicto committing adultery. Under this model, the concept of triple hymenization is irrelevant.

Note, however, that the passion model is not allowed to dominate the Codes that incorporate it. They find their own compromises on the idea of passion. The Egyptian Code, for instance, excludes the wife as beneficiary. The Algerian, on the other hand, includes only spouses, excluding lovers.

But even those Codes that lie at the honor end of the spectrum, say the Jordanian Code, are influenced by the ideal of passion. It demands the "passion" requirements of in flagrante delicto, surprise, and immediacy in killing, requirements that are not part of the traditional conceptualization of honor.

\section{Conclusion}

The various ways in which Arab Codes regulate honor killings can be seen as diverse attempts by national legislatures to respond to the private violence of honor killings. In general, each Code seeks to de-legitimize the honor killings that are at the crux of an honor model (nonvirginity on the wedding night and illegitimate pregnancy), it nevertheless stops short of substituting passion for honor. At the same time, while each incorporates some elements of the crime of passion, namely flagrante delicto, surprise and immediacy, each 
stops short of fully adopting the model of passion. In summary, all the Codes simultaneously reject pure honor as well as pure passion as their underlying paradigms.

\section{The Nationalist Project}

Where did the spectrum of honor/passion originate? Is there an explanation for the variety of ways in which the question of honor killings was resolved in the various Codes? What is the nature of this legislative activity of selection from a pool of different and conflicting elements? Is it peculiar to the issue of crimes of honor or is it more broadly symptomatic of the modern phenomenon of codification in the Arab world? Who were the codifiers, and what ideological motivation did they have when they engaged in the activity of legislative selection?

The structure of honor-crime regulation in the different Codes, based on the idea of selection and compromise, is a particular mode of regulation that mimics and repeats the approach to wholesale codification adopted by Arab national elites on the eve of independence from European colonialism. It is simply a particular example of a more general phenomenon of legislation.

These national elites were naturally preoccupied with modernizing the institutions of the newly independent states, in particular with providing a foundation for a rule of law ideology. To that end, they passed modern Codes regulating various areas of life: Commercial Codes, Criminal Codes, Civil Codes, and Personal Status Codes. But being nationalist, they also sought to reproduce "tradition" as the locus of the identity of the new "nation." Striking a balance between "tradition" and "modernity" in the multiple activities of state building, especially in the area of codification, thus became the mark of the government of the nationalist elites. ${ }^{18}$

\section{A. The Judicial Treatment of Honor Killings in the Arab World}

In this section, I examine judicial decisions involving honor killings from Jordan, Egypt and Syria. The overall picture that emerges

18. What I mean by the nationalist elites, or the nationalists, is the ruling group with whatever pronounced political label, be it FLN, Ba'th, Arab Nationalist, Royalist, Marxist, who took over the government of the nearly-independent states of the Arab world. I call them "nationalists" in the broad sense for two reasons: first, they all shared "the sentiment/ideology" that Arabs constitute one nation, and the ideal that the Arab world should be united; second, they were nationalist in the sense that the task they undertook of modernizing the institutions of the state, started the historically irreversible process of imprinting on the consciousness of the population of their own particular state a sentiment/ideology of local nationalism. Through government curricula, media, institutional indoctrination, the people of Algeria started to see themselves as Algerians, of Jordan as Jordanians, of Lebanon as Lebanese, etc. This is despite the simultaneously running belief that "we are all Arab" that everybody seemed to share. 
is one of difference-splitting, but with the judiciary tending toward a more traditionalist approach than the legislator.

\section{The Jordanian Court of Cassation}

Looking at actual court cases from Jordan between 1953 and 1982, we encounter a surpise: Article 340 of the Criminal Code turns out to be of little relevance to the adjudication of honor killings. A completely different and far more general Article is applied, i.e., Article 98:

He who commits a crime in a fit of fury caused by an unrightful and dangerous act on the part of the victim, benefits from a reduction of penalty.

The Jordanian Court of Cassation (JCC) did not always treat Article 98 as the most relevant one to killings of honor. In fact, between 1953 and 1965 (perhaps even before then, but there is no way of knowing for certain because there was no criminal case reporting before that period) the JCC strongly resisted this particular way of framing the legal response. During that period, not only are we unable to find a single case in which Article 340 was applied, we actually find many cases in which the JCC argued against the application of Article 98. The JCC's resistance was based on two arguments.

First, the court tended to reject the argument that the female victim's behavior, seen by the accused as violating his honor, constituted an "unrightful and dangerous act." The court chose to lay down a very rigorous and precise meaning for Article 98 by arguing that nothing less than "a minor case of self-defense" would justify applying it. The JCC clearly thought that any dishonorable act that the woman might have committed hardly amounted to such a case of "minor self-defense." Thus, in a 1953 decision, whose radicalism will become glaringly apparent when compared with later cases, the Court decided that a woman's illegitimate pregnancy did not constitute an "unrightful act" within the meaning of Article 98, and accordingly refused to grant the accused a reduction of penalty. ${ }^{19} \mathrm{In}$ another decision, reasoned in a vague and ambiguous way, the Court decided:

The shameless behavior of the victim is not considered an unrightful act for the purposes of article 93 [the historical origin of Article 98 before the Penal Code of 1960 was passed], and cannot be seen as calling for a reduction of the penalty, unless the act of killing occurred while the defen-

19. Jordan Court of Cassation, $53 / 53$ at 578 (1953). 
dant was in a state of surprise at seeing one of his female unlawfuls in an un-lawful bed. ${ }^{20}$

Second, the JCC insisted ${ }^{21}$ on treating Article 93 (now 98) as a general provision and Article 333 (now Article 340) as specific. The Court thus argued that killings of honor are specific crimes and, consequently, only the specific criminal provisions dealing with issues of honor killings can be applied to them. When there is a specific provision, the Court reasoned, you cannot apply a general one, because the specific constricts the general.

In 1964, however, the Court's resistance started to break down and it proceeded to reverse its previous position. In that year, it conceded the applicability of Article 98 to killings of honor, thus paving the way to a body of decisions that have since then come to define the parameters of the crime of honor until our present day. In one case the Court argued that:

Article 340/2 of the Penal Code provides for a reduction of penalty in a specific case which is that of the defendant catching one of his ascendants, descendants or sisters in an un-lawful bed. While Article 98 is more general, the defendant benefits from a reduction if he has committed his crime in a fit of fury caused by the victim's unrightful and somewhat dangerous act. ${ }^{22}$

Contrary to its previous position of adhering to the general vs. particular distinction in addressing these crimes, the JCC came to treat Article 98 as complementary to Article 340, so that if the rigorous conditions laid down by the latter were not fulfilled in a certain case, the court would revert to Article 98 to "save" the defendant. It would do so by latching on to the element of fury which is always present in honor killings. What used to be a distinction between an assault on the person of the defendant, calling for the application of Article 98, and an assault on the honor of the defendant, calling for the application of Article 340, was now collapsed: an assault on honor is equivalent to an assault on the person.

If the defendant learnt that his daughter had committed adultery at the moment that he killed her, then he is considered to have killed her in a fit of fury caused by the act that she had committed. Her act constitutes an unrightful attack on the defendant's honor and it is dangerous within the meaning of article 98 of the Penal Code. ${ }^{23}$

20. Jordan Court of Cassation, 8/53 at 263 (1954).

21. This starts to become apparent in the above-quoted decision of 1954 .

22. Jordan Court of Cassation, 59/64 at 1036 (1964).

23. Jordan Court of Cassation, 5/67 at 221 (1967). 
The JCC's clear rejection of what were previously its two most prominent arguments against applying Article 98 is best exemplified by a decision of 1975 :

The fact that the Code provides for a reduction of penalty in a specific provision does not mean that the court cannot apply the general provisions of the Code such as Articles 97, 98 , as well. The general rules are applied when the specific rules don't apply to the particular case. The victim's act of adultery is a material act that touches the defendant's honor and that is why it is not a violation of the law to grant him a reduction of penalty. ${ }^{24}$

Once the court made the move to apply Article 98 to crimes of honor, we find that its decisions in the aftermath of this radical reversal are preoccupied with addressing three issues.

First, the nature of the act committed by the woman, i.e., does the act amount to an unrightful act against the honor of the family? In one case, the court said yes:

The victim's illegitimate pregnancy constitutes an unrightful assault on the family's honor, an act of extreme dangerous nature according to our society's traditions. Therefore, the defendant benefits from a reduction of the penalty if he killed his daughter in a fit of fury according to Article $98 .^{25}$

Second, the issue of time, i.e., how much time had passed between the defendant's knowledge of the victim's unrightful act and the killing? Here, the courts tended to allow considerable delay;

If the defendant killed his sister the minute he found her, two days after he had learnt that she was caught committing adultery with another, then the killing was done in a fit of fury caused by the victim's unrightful and dangerous act. ${ }^{26}$

The fact that the defendant killed his sister one day after he became certain that the rumors surrounding her illegitimate pregnancy were true, is not sufficient evidence that he committed premeditated murder, since this period is not enough for him to regain his sensibilities and calm down. ${ }^{27}$

Third, how did the defendant learn of the victim's act? Here, we find somewhat contradictory holdings. In one case, the Court reasoned:

24. Jordan Court of Cassation, 30/75 at 1021 (1975).

25. Jordan Court of Cassation, $11 / 78$ at 458 (1978).

26. Jordan Court of Cassation, 19/68 at 494 (1968).

27. Jordan Court of Cassation, 58/73 at 840 (1973). 
The fact that the defendant killed the victim after hearing rumors that she had committed adultery, does not allow him to benefit from a reduction of penalty according to Article 98 , because the victim cannot be said to have committed an unrightful and dangerous act. ${ }^{28}$

If the defendant heard of a rumor that his sister had committed adultery and consequently asked her and was confirmed, then killed her immediately, Article 98 applies to him. ${ }^{29}$

The Jordanian example shows how, early in the nationalist project, Article 340, the directly applicable provision to honor killings, or "the particular provision," was marginalized by the court and replaced with Article 98, "the general provision," which deals with crimes committed in a fit of fury (self-defense). The moment in which Article 340 was displaced for the benefit of Article 98 can be seen as the JCC's adoption of an attitude that tolerated honor killings by expanding the sphere of circumstances under which defendants can benefit from the excuse of reduction. Determining the exact boundaries of this sphere hinged on the way the Court chose to address the victim's act, passage of time, defendant's knowledge in its application of Article 98. In so far as I can tell, there does not seem to be a pattern in the court's decisions on these questions providing us with a clear sense of the boundaries between what would be tolerated and what would not. ${ }^{30}$

\section{The Egyptian Court of Cassation}

As I indicated above, Egypt has one of the more "liberal" provisions dealing with honor killings. What I mean by "liberal" is that the beneficiaries of the excuse (reduction, not exemption) are limited to the husband, and the excuse is available to him only when he catches his wife committing adultery red handed. In other words, it is a strict provision that severely limits the pool of beneficiaries and the occasion that warrants such an excuse. Its strictness is reminiscent of the concept of a crime of "passion" rather that of "honor."

Article 237 of the Egyptian Penal Code No. 58, 1937, states:

He who catches his wife committing adultery and kills her and her partner instantly, is punished by prison instead of the penalties provided for in Articles 234, 236. ${ }^{31}$

28. Jordan Court of Cassation, 90/81 at 1770 (1981).

29. Jordan Court of Cassation, 88/70 at 962 (1970).

30. The ratio of honor killings to all other homicides committed in Jordan (according to Jordanian police records) was $33.3 \%$ in $1986,26.5 \%$ in $1987,30.3 \%$ in 1988 , $32.2 \%$ in $1989,26.2 \%$ in $2990,31.5 \%$ in 1991 .

31. Egyptian Penal Code, No. 58, art. 234 (1937) deals with the crime of killing "with intent but without premeditation," punishable by permanent or temporary hard 
From a comparative point of view, two things are striking about the Egyptian regulation of "honor" killings: first, the limited application of the Egyptian Article 237 (only in the case of "wife") compared with the Jordanian one (unlawfuls/ascendants/descendants). Second, the Egyptian Code does not have a "provocation rule," i.e., the equivalent of Article 98 of the Jordanian Penal Code. Commenting on this issue, an Egyptian jurist writes:

It is noteworthy to mention that the Egyptian legislature did not consider "provocation" as a general excuse. There are specific excuses limited to a specific number of crimes such as the excuse granted to the husband who catches his wife committing adultery flagrante delicto under Article 237. This excuse is only a specific kind of provocation rule. ${ }^{32}$

Because the Egyptian Code does not have its own general rule on provocation, the position of the Egyptian courts oscillating between the rule on provocation and the rule that deals with flagrante delicto (Article 237), as was the case in Jordan, does not exist. Rather, if the strict application of Article 237 makes its excuse unavailable, judges can only resort to extenuating circumstances under Article 17:

In crimes requiring the sympathy of the court, the judge can replace the penalty in the following way, in place of capital punishment, permanent or temporary hard labor, etc.

The trier of fact can take extenuating circumstances into consideration in its sole discretion and even if the accused did not plead for it. If invoked, it is not a question of law and thus cannot be appealed to the Egyptian Court of Cassation (the ECC). ${ }^{33}$

In one case, the ECC decided that:

Since the defendant did not kill his wife upon catching her flagrante delicto committing adultery, rather, having heard rumors about the fact, he returned to his village, entered his house and finding a strange man's clothes in his house, became furious and killed both his wife and mother-in-law, [thus] Article 237 did not apply. This is so because legal excuses are an exception that cannot be analogized to. ${ }^{34}$

labor. Article 236 deals with the crime of killing by intending to "only harm or injure them," punishable by temporary hard labor or imprisonment from three to seven years.

32. Rauf Ubaid, The General Rules of the Egyptian Penal Legislation 863 (1964).

33. Id. at 864 .

34. Egyptian Court of Cassation, No. 615 (Judicial yr. 46, 1967). 
In this case, the ECC rejected the defendant's appeal for "mercy" holding that mercy was solely within the jurisdiction of the lower court.

In another case, a man who had discovered that his unmarried daughter was not a virgin and killed her instantly in a fit of fury argued that he was suffering from a temporary loss of sanity and thus protected by Article 62 of the Penal Code. The defendant was trying to use this Article instead of the rule of provocation that was unavailable to him. The ECC rejected this argument:

According to Article 62, the excuse of exemption is granted only to him who loses . . . choice due to loss of sanity or a defect in his thinking... and since the defendant was merely in a state of excitement and was provoked to commit the act then he could not be said to have been suffering from insanity ... . [I]n cases of provocation only a discretionary judicial excuse of reduction is available to the defendant which is totally up to the court of fact over which the Court of Cassation has no jurisdiction whatsoever. ${ }^{35}$

The above cases reveal that in Egypt, honor killings that cannot be accommodated within the strict sphere of application of Article 237 are typically left to the discretion of the lower courts of fact as cases requiring the sympathy of the judge under Article 17. As these decisions are not published, it is hard to tell which cases win these courts' sympathy and which do not. In other words, it is not clear how the boundaries of these crimes are being delimited by the Egyptian lower courts and how differentiation between the cases is being carried out.

\section{The Syrian Court of Cassation}

The Syrian Penal Code specifically excuses ${ }^{36}$ crimes of honor. Article 548 states:

1. He who catches his wife or one of his ascendants, descendants or sister committing adultery (flagrante delicto) or illegitimate sexual acts with another and he killed or injured one or both of them benefits from an exemption of penalty (an absolute excuse).

2. He who catches his wife or one of his ascendants, descendants or sister in a "suspicious" state with another (attitude equivoque) benefits from a reduction of penalty.

Article 548 has its source in the Lebanese Penal Code (Article 562 ), which it adopts almost word for word. Both articles, the Lebanese and the Syrian, are themselves adaptations of the French

35. Egyptian Court of Cassation, No. 71 (Judicial yr. 42, 1972).

36. No. 148 of 1949 has in its Article 548 (as modified in the Legislative Decree No. 85 on Sept. 28, 1953). 
provision, the primary source of the Lebanese Penal Code (Law No. 340,1943 ).

In addition to Article 548, the Syrian Code has its own provocation rule, Article 242, which is almost the same as that of the Jordanian Code. Both the Syrian and the Lebanese Codee include an "honorable motive rule." Syrian Article 192 states:

Once the judge recognizes that the motive was sympathetic he will apply the following sentences: life sentence instead of pain of death, life sentence or fifteen-year imprisonment instead of life with hard labor.

It is important to note that this is not the "extenuating circumstances" rule that exists in the Egyptian and Jordanian Codes, and which the Syrian Code provides in Article 243:

If it falls under the extenuating circumstances, then the court will apply a sentence of $12-20$ year imprisonment instead of life with hard labor. The time of hard labor shall not be less than 10 years.

It is impossible to tell from the face of the Codes which defensethe honorable motive rule or judicial sympathy for extenuating circumstances-is more beneficial to the defendant.

In sum, we see that a defendant in Syria charged with committing a crime of honor has a pool of rules that could be applied to his case: (a) Article 548 and (b) Article 192 (the honorable motive rule), (c) Article 243 (the extenuating circumstances rule) and (d) Article 242 (the provocation rule).

If we look at the Syrian cases closely, ${ }^{37}$ we see that the locus of the struggle is not the relationship between the provision that directly regulates the crime of honor and the provocation rule, as was the case in the Jordanian courts. As if taken for granted by the Syrian courts that, if the requirements of the direct provision do not prevail, the judge should look to other provisions, and there is a whole pool of them. The choice between direct provision and provocation rule does not come up in Syria. Indeed, the struggle seems to have been displaced to the relationship between the provocation rule and the honorable motive rule. It is an important struggle given the difference in the reduction of penalty between the two: under the

37. Due to lack of space I will not be able to provide a detailed exposition of the Syrian cases I had looked into (from 1957 to 1982). I will, therefore, limit myself to a commentary on the following cases: SYRIAN COURT OF CASSATION, 264 (dec. 408, 1957); Syrian Court of Cassation, 144 (dec. 158, 1958); Syrian Court of Cassation, 358 (1963); Syrian Court of Cassation, 487 (1964); Syrian Court of Cassation, 291 (1965); Syrlan Court of Cassation, 402 (1965); Syrian Court of Cassation, 443 (1966); Syrian Court of Cassation, 291 (1965); Syrian Court of Cassation (dec. 6, 1970); Syrian Court of Cassation, 451 (dec. 627, 1982). 
provocation rule the reduction is much more significant. In the cases decided in 1957, 1958, 1965, 1966 and 1982, we see the Court insisting on the application of honorable motive rule and refusing to apply the provocation provision. In effect, it insisted on the harsher penalty. These were all cases where the requirements of Article 548 were not satisfied. However, in a case decided in 1964, and one decided in 1970 , the Court seems to have applied the provocation rule instead of the honorable motive rule.

In contrast to the Jordanian story of resistance and then, at a particular historical moment, surrender to crimes of honor, Syrian courts have not shifted from being harsher on the defendant to being more lenient. Istead, the Syrian Court of Cassation (SCC) seems to vacillate from one position to the other, though ultimately leaning, in the majority of the cases, in the direction of the honorable motive rule and thus toward being harsher on the defendant.

One can characterize the Syrian courts as manifesting a stronger desire than their Jordanian counterparts to penalize the offenders, since the penalty provided for in the honorable motive rule is greater than that of the provocation rule. Nonetheless, they do share with the Jordanian courts the desire to "reconstitute" the crime of honor by circumventing the application of Article 548. In other words, if the rigid requirements of Article 548 were intended by the codifiers to delegitimize certain honor killings (for instance, those based on the pregnancy of the victim), the Syrian courts have chosen to thwart that attempt by invoking other readily available provisions to partially legitimize these killings. Thus, the "story" of the Syrian judiciary is one of an attempt to re-legitimize traditional honor, but only in a relative sense since, in cases where censure is found deserving, they tend to choose the harshest penalties available in the pool of alternative provisions.

What seems to unite the practice of the judiciaries in Jordan, Egypt, and Syria is the tendency to introduce other criminal provisions when presented with a killing of honor. In doing so, they seem to mock the nationalist codifiers, who had drafted honor killing provisions that carefully calibrated the relationship between passion and honor, and struck what they thought was a careful balance between the two. The ability of the judiciary to create alternative legal frameworks to interpret honor killings is a statement on the instability of the nationalist regulatory system based on the idea of balancing acts. It is even more noteworthy that this subversive practice by the judiciary is going in one direction rather than the other. In other words, the judiciaries seem to be using their ingenuity to reintroduce the idea of traditional honor, rather than pushing the system to be passion-based. As we have seen, both ideas are inherent in the nationalist compromise. The fact that the judiciaries have a tendency to 
push in one direction (honor) rather than the other (passion) highlights the judges' own relative cultural conservatism.

At the same time, one must note, however, the judiciary's own ambivalence towards honor killings and its own uniquely crafted attempt to strike yet another balance which is different from the legislative one. Though the Syrian judiciary, for instance, opts to use the honorable motive rule in lieu of the directly applicable provision, it nevertheless grants the lower court the power to introduce the extenuating circumstances rule. In other words, though the judiciary reintroduces the idea of traditional honor, it does not do it completely or wholeheartedly. Its practice remains constrained and limited. The nationalist balance seems to have been displaced, through judicial practice, by another balance, equally vulnerable and unstable. This should come as no surprise, since the judiciary shares with the codifiers the essential nationalist ideology of striking a balance between tradition and modernity.

Why this ambivalence? What were the nationalist legislators and judges responding to?

\section{B. Women and the Family in the Ideology of the Nationalist Elite}

The post-colonial Arab nationalist elites sought to produce a new (national, post-independence) woman: she is literate and educated in the nationalist curriculum designed by her government at the dawn of independence. ${ }^{38}$ She is even, in many cases, employed. Education, and to a lesser degree, employment, quickly became not only respectable undertakings for this woman, but also socially expected. Education was meant to groom her, to refine her with modernity. On the one hand, she must never be her mother: illiterate, secluded, and ignorant of the public world. But just as she was not to resemble her mother, she should also equally resist becoming simply a "Western woman." Education was meant to help her become a better wife and mother, to enhance and modernize her femininity, not jeopardize it. On the other hand, there must never be any confusion in her mind, as to her essential difference from men. Though educated, the new woman must not lose sight of the fact that her education is not meant to rob her of her true place, the home. Work and the external world are for men, family and the spiritual world of the home are for her. Through education she raises happier and healthier children, and

38. The nationalists borrowed their construction of the "modern woman" from writings by Arab renaissance writers and their disciples who believed in some form of Arab nationalism or even Islamic nationalism. See, for instance, BUTROS AL-BUSTANI, The Education of Women, reprinted in The Teacher Butros al-Bustani (Fuad Afram al-Bustani ed., 1929); RIFA'A TAHTAWI, GUIDING TruTHS For GIRLS AND Youths (1873); Qasim Amin, The Liberation of Women (1953). The general idea in these writings was that women should be educated since this will turn them into an asset for the nation, through their roles as mothers who bring up good sons. 
she is refined to be publicly presentable in the company of her husband. If and when she is employed, she should relegate her employment to a secondary position. Family comes first; everything else is marginal to that.

Through this arrangement, nationalist ideology accomplished a double feat: on the one hand, the new Arab woman was modernized, on the other, the family, the main asset of the nation and the vessel of its national/cultural spirit, was preserved.

The construction of the new national woman had the effect of displacing the previous boundaries of the physical and the social hymens that women used to perform. In the new nationalist context, women began to look and behave differently, wear Western clothes in contrast to the veiled/"scarved" look of their mothers, mix with their husbands' friends, and leave the confines of the home to gain a noticeable presence on the streets of the cities. The new boundaries constructed by the nationalist project, however, were no less culturally determinate than the previous ones. The boundaries may have changed, but "fixed" boundaries they remained, or so the nationalists hoped.

The nationalist post-independence movement required, then, new gender performances of men and women. A new list of licenses and prohibitions came to take shape, slowly and painfully, to accommodate the emergence of the new woman. For example, the new middle-class man does not experience a diminution of his maleness if his sister discusses her course work with a male university colleague. From the "bosom" of traditional patriarchy, a new nationalist patriarchy was created.

The move was not entirely peaceful. Expectedly, some men found themselves recalling traditional patriarchy with wistful nostalgia. The reaction was generational, of course, with the younger generation having a more tenuous connection with the older patriarchy than the preceding one. However, these moments of nostalgia could produce erratic and unpredictable incidents of violence: the same new man who does not object to his sister discussing her course work with a university male colleague may very well threaten to kill her for honor if he saw them having coffee together or interacting joyously in a public place. One might say that these occasional incidents of violence were (and still are) the way nationalist patriarchy keeps its new list of licenses and prohibitions well-recited and precise. The moment the balance of the "modern Arab woman" is pushed too hard in the direction of "Westernized sexuality," it is met with the threat of violence. This is precisely the type of violence the Arab judiciary seems to condone. 


\section{Conclusion}

While in general the different nationalist codifiers in the Arab world were engaged in striking a balance between passion and honor, the specific compromise that each country chose is, in all likelihood, simply the function of the eclecticism of the nationalist codifier. The various solutions were, to a great extent, superficial ones. The nationalist balancing system proved to be unstable. Through its attempts to reconstitute traditional honor by effectively dismissing the internal structure of the codified excuse and by creatively attempting to legitimize certain crimes, the judiciary highlights, in its practice, the superficiality of the nationalist choice.

The nationalist state policies that aimed at producing the "modern Arab woman" also proved to be inherently unstable. Modernizing women in the nationalist style failed, as I show below, to preclude those erotic and amorous practices that recall in the minds of many that terrifying thing: "Western sexuality."

This leads to the question why the judiciary tended to react conservatively by reconstituting a more traditional version of honor? What is it that they were attempting to address?

Although the members of the judiciary were themselves nationalist and acceded to the nationalist project of modernizing women and the family, they were nevertheless faced with the task of remedying the tendency of the nationalist policies to run amok. The nationalist project had had the effect of producing new sexual types and practices that could be seen as both products of the new system and resistant actors to and within it. These sexual types and practices were the nationalists' nightmare: they were the products of the nationalists' own policies, yet ones that nationalist ideology consciously rejected. Unleashing periodic private violence against these types, through the permissions granted to it by the Arab judiciary, was essential to keep these types and practices in check. This then appears to be the new social function of crimes of honor: rather than representing an attempt to reconstitute traditional society, they were a response to emergent sexual types and practices in the nationalist social regime. This, in turn, explains the judiciary's attempt to reintroduce traditional honor, but only to some extent. The judges consciously rejected the reinstitution of traditional society but they were sending cultural messages that subversive sexual practices were not to be tolerated.

To understand this dynamic, we need a typology of sexual types in the world produced by Arab nationalism. 


\section{A Sexual Typology of Arab Women under Nationalist Patriarchy}

In this section I develop a sexual typology of Arab women under nationalist patriarchy. I do so by fleshing out the highly varied relationships that women have with the most popular Arab female dance, the belly-dance, otherwise known in the Arab world as sharqi, baladi, or raqs 'arabi. ${ }^{39}$ In many ways, this dance is one of the very few socially legitimate venues through which modern Arab women express themselves sexually in public. Belly-dancing is widely viewed as a highly erotic art, especially when performed by professional dancers. However, when performed by Arab women across class lines, the eroticism associated with the dance is continuously renegotiated, teased out, or, in rare occasions, flaunted.

There are two sides to the belly-dance that one must keep in mind. First, it is a social activity, particularly among women in their own segregated social gatherings (parties, weddings, celebrations). Second, it is an artistic activity, performed by professional dancers in nightclubs, restaurants, theaters and films. The costume that the belly-dancer wears is very sexy, reinforcing the dance's eroticism, and accentuates the heavy shaking of the hips and the breasts.

In the past, dancing was always an activity performed only in the company of other women. Typically, each woman would step into the middle of the circle and take her turn dancing, while other women surrounded her, clapping their hands and ululating in encouragement. In that setting there was no distinction between performer and spectator: everybody danced, often two or more women danced together, or to each other. Frequently, these performances turned into "bride-choosing" occasions, where one woman would report to her son the dancing of a girl that she liked, soliciting in her description his desire for a partner. ${ }^{40}$

An important change occurred when these women started performing the belly-dance before a male audience. The change is virtually simultaneous with the intervention of the nationalist text. With women's education and employment, the public space progressively ceased to be segregated, and social gatherings (mostly familial in the extended sense) came to include men and women in a desegregated space. This was an important moment in the history of Arab women's sexuality: it allowed women, through the belly-dance, to communicate erotically with their male voyeurs. There is no longer a mediator (the mother) describing the dancing girl to the son; the son

39. For my discussion of belly-dancing I have relied on WENDY BuONAVENTURE, Serpent of the NiLe: Women AND Dance In the ARAB World (1989), a unique text that attempts to provide a history of belly-dancing and to theorize it both as an art form and as a social practice.

40. Id. at 159. 
is now present in person getting his firsthand visual experience. The woman seduces him through her dance, and may very well find herself approached and wooed by the man without a third party. Here, the woman parodies the belly-dancer as the publicly seductive female. By assuming some of the dancer's sexual powers, she captures the heart of her male spectators and solicits their requests to the respectable end of marriage. To this day, these mixed celebratory gatherings remain bride-choosing occasions.

Granting women education on a mass level, and then later employment, constituted a serious bombardment of male space. Daily verbal exchange between the sexes came to be tolerated and seen as inevitable (albeit often grudgingly). Virginity had to catch up, so to speak, and the gendered actors started to develop a new code of behavior (and dress) that could accommodate interaction between them, and yet also provide a convincing (and necessarily novel) performance of women's virginity. This new behavioral code was particularly tricky to enact given the ambiguity and complexity of the new situation. The ambiguity of the new code of behavior and the constant negotiation of its rules by its gendered actors generated a rich and confused institution of gossip. Determining the rules of the sexual code governing the interaction of men with women in the workplace remains to this day a mystifying task that escapes the grasp of the people involved. ${ }^{41}$

Belly-dancing was a site of this new ambiguity and confusion. Women'sbelly-dancing in the desegregated public space of social gatherings and celebrations resembles to a large degree women's work in a desegregated workplace. Determining a code of dancing that allows a performance of virginity, given the erotic "stuff" that belly-dancing is made of, is by no means an easy task. And yet, if anything, it testifies to the deep change that the performance of virginity has undergone: from the almost complete shunning of any sexual expression within the confines of the traditional society, to an ambivalent cultural acceptance of such expression in the context of the nationalist social regime.

Repeating the old rituals of belly-dancing within women's gatherings, women still dance with and to each other in the new desegregated public place. Now, however, their consciousness is besieged by an awareness of the male gaze. It is a gaze that itself is very ambivalent. It appreciates and condemns. It wants to be seduced, yet is harshly judgmental of the propriety of the dancer. Whereas the appreciative gaze of the male voyeur drives women to be more seductive, the judgmental one pushes them to be reserved in their

41. For an excellent discussion of the confusion in the code of sexual behavior that had accompanied the desegregation of the workplace, see Elizabeth WARNOCK Fernea, Women and the Family in the Middle East (1985). 
movements. Keeping the balance may be a hard thing to do, but most women have mastered, unconsciously, the act of "walking a tightrope." After all, today these party/wedding gatherings are rich matchmaking occasions. ${ }^{42}$

Let us begin by calling these women the sexy virgin(s).43 One indication of their lurking virginity is that they seem to be quite unaware of their sexiness. Virginal sexuality is a unique form of sexuality that colors the woman's fantasies, relationship to her body and erotic responses in general. There is a certain sexual girlishness and naiveté associated with the state of being a virgin. Such a woman cannot fully comprehend the extent and nature of her sexualization by the male voyeur. If men's sexual fantasies about the dancing sexy virgin were revealed to her, she would react with embarrassment, shock and shame. Her virginal understanding of men's appreciative gazes is otherwise interpreted by her as an appreciation of her beauty, attractiveness, and cuteness. In no way is she capable of indulging herself in the complex, terrifying world of the male, virginby-default sexuality.

Virginal sexuality has a tendency to turn inward. In other words, the sexual desire for the other seems to transcend itself, in the sexy virgin, and turn into deep narcissism. These women, who appear not to be fully aware of their sexual powers over men, are at the same time simply in love with their looks. Always adorned with nice clothes, jewelry, and heavy make-up, and deeply conscious of how they look, they continuously exchange admiring looks with each other and are much more at home with their reflection in the mirror than with the male gaze, an experience that reconstitutes, on a small scale, the traditional society where the male space and the female space were segregated. ${ }^{44}$

42. The belly dancer's "shameless" shaking of the hips and breasts, her lewd immodest erotic movements turn, at the hands of these women, into girlish bashful embarrassed gestures that invite boredom, impatience, and restlessness in me as a female voyeur who is enamoured with the belly-dance.

43. For my sexual typology of Arab women I have relied on several modern Arab novels, interviews I have personally conducted, as well as my own observations of men and women in my life. The novels include: SaHaR KHALIFAH, MudhakKIRAT ImRA'

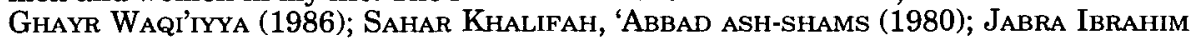
Jabra, BaHth 'an Walid Mas'ud (1978); Jabra Ibrahim Jabra, The Ship (Adnan Haydar \& Roger Allen trans., Three Continents Press, 1985) (1970); Hoda Barakat, THe Stone of Laughter (1995); Ghadah Samman, Beirut 75 (1975); Rachid Boujadra, al-INkar (1984); Ibrahim Aslan, Malek al-hazin (1993); and Ghassan KANAFANI, AND WHAT IS LEFT To You? (1977). I have also found very helpful a number of interviews with Lebanese women talking about their sexual lives published in Bouthaina Shaaban, Both Right- and Left-Handed: Arab Women Talk about THEIR LIVES (1988).

44. This situation produces a particular anomaly in that the consumption by the "sexy virgin" of Western fashion does not necessarily mean that she is aware of the sexual messages that are delivered with this kind of garb, themselves cultural effects of Western sexuality. 
The violence of the honor universe has a serious disciplinary effect on the sexy virgin. She is unwilling to take risks that would make her a potential victim of a crime of honor. She is the virgin of the traditional society who is utilizing the sexual space opened up by the nationalist project.

At this point, we need to introduce the class factor into the analysis in order to explain the second persona in my typology: the virgin of love. In the upper classes of Arab society, belly-dancing as a collective dance has suffered a certain diminution of value. Though upperclass folks still invite belly-dancers to celebrate their son's weddings, the actual practice of belly-dancing among upper-class women has diminished dramatically, so much so that most upper-class women harbor a certain feeling of contempt for the dance and the people who perform it. The progressive Westernization of this class meant the devaluation of Arab cultural arts such as Arabic music and bellydancing. Belly-dancing came to be seen by these women as a dance performed professionally by vulgar women, and socially by "common" women.

These women are thus deprived of the pleasure of publicly communicating with men at weddings and social gatherings in a sexual way. As they sit in their seats watching other women dance, they experience mixed feelings best described as envious contempt. Often, these women are the virgins of love. They believe in love and might even commit the revolutionary act of engaging in underground sex with their lovers (mostly precluding coitus, and mostly with lovers who had spent a long time courting them first), but they remain contemptuous of any public expression of sexuality. Their virginity manifests itself not in their private lives but in their public ones. Whereas the sexy virgin engages in acts of seduction in her bellydance to attract a potential suitor and is afraid of engaging in the underground life of "sexual love," the virgin of love rejects public acts of sexual attraction and remains glued to her seat: pure, awaiting the fall of love from the sky. The first engages in sexy acts in public which she does not fully comprehend, while the second engages in secret subversive acts of sex with the man she is madly in love with and dismisses public sexual expression as vulgar. In this, both are making a statement of their virginal sexual consciousness. Virginity survives, albeit transformed, in the nationalist context. ${ }^{45}$

The virgin of love takes more risks than the sexy virgin. Utilizing the mobility and social space that her upper-class environment allows her, she is able to conduct a sexual life, albeit underground. Armed with a rhetorical arsenal on love and romance that justifies

45. The virgin of love, often upper class, has the self-image of being a modern woman, which in her mind means belief in romantic love as the only legitimate basis for companionship between the sexes. 
her conduct, this woman is relatively willing to challenge the universe of honor's codes of conduct. But she is in little danger: as we will see, only women of lower social background are subjected to the threat of honor killing.

The third sexual type in my line-up is the coquette. This woman is an anomaly in Arab culture, and somewhat inexplicable. Usually she is married or divorced. She is flirtatious to various degrees, consciously sexy with men, and appears to the male gaze to be the most skillful in exploiting the eroticism inherent in the belly-dance. In fact, this woman, upper-class or not, is invariably enamored with the dance. She performs it most artistically and is freer in shaking her hips while she keeps an inviting and seductive look on her face. Most of the time she dances in the company of her husband (or brother), thus securing a certain social protection from the label of "slut." This woman is unusually friendly, free, dynamic, and very funny. She cracks jokes continuously, particularly sexual ones, often in the company of men. She is tolerated by her audience because she is or has been married, a fact that explains her sexual savvy. The coquette is deeply desired by men, while being adored, envied and hated by women. Sexy virgins watch her with shock and glittering eyes. Virgins of love watch her with contempt and resentment. She is a figure to be both instructed by and to avoid. Women's ambivalence towards her is explained by their desire to learn from her, since she seems to enact a style of behavior that is taboo for them. At the same time, she seems to smack so much of the slut they have so much repressed in themselves. That is why they both want her company and run away from her. Her ability to rescue herself socially, as the flirtatious wife of soand-so (and not the slut), never fails to deeply impress them. Her coquettishness does not seem to particularly doom her socially, though it does doom her husband. He is seen as a wimp, unable to satisfy or contain his wife's sexuality.

The subversiveness of the coquette's presence in any social setting is not to be underestimated. You see her on the dance floor freely shaking her body, trying to teach other women how to do it. Her friendly and flirtatious behavior with men can become contagious, giving courage to the women in her company to cross boundaries they never considered crossing before. She is the closest to the figure of the artistic belly-dancer: sexy, flirtatious, sought-after, admired, but secretly suspected of being loose. The coquette is, relatively speaking, a risk-taker. Her sexual conduct is allowed to exist because of her rather "equivocal" status. Her family sees her as the responsibility of her husband, in most cases a man who either behaves like, or is perceived as, a cuckold. Her equivocal status, however, is sometimes resolved unpredictably, when the husband/cuckold decides, all of a 
sudden, to redeem his honor. The coquette then becomes the victim of a crime of honor.

My fourth sexual type is what I call the GAP girl. She is an interesting combination of the coquette and the sexy virgin. She shares with the latter some aspects of her virginal sexuality and with the former her easy and comfortable access to the world of men. I call her the GAP girl because she comes to the dancing floor dressed in jeans, T-shirt, and sneakers or low-heeled shoes. She is the die-hard child, holding fast to her pre-adolescent virginity. She enacts the infantilizing effects of required virginity. The GAP girl looks asexual. Unlike the sexy virgin, she is not conscious of her sexuality, even in the virginal sense, so she avoids the struggles the former must engage in order to negotiate her sexual desires in fear and shame. However, she is similar to the sexy virgin in that she is totally ignorant of the sexual world of men. Her childish look and body (she typically has short hair and wears no make-up) allows her to have comfortable and friendly interactions with men that could include a great deal of physical contact. She gets away with it because it is all done in innocence. They are all her friends. She is most at home in desegregated institutions of leisure, such as youth clubs and sports clubs. In fact, she is often the sporty type.

When this girl goes to the dance floor, she is usually with a group of male and female friends. She dances with men with the same ease that she dances with women, treating the dance as more of a sporty and fun activity than an erotic and aesthetic one. When she grows older, if and when she decides to, she usually develops into the virgin of love. Her intense familiarity with men makes it difficult for her, however, to become the sexy virgin. And her delayed sexuality makes it almost impossible for her to become the sexually sophisticated coquette. The GAP girl does not have to deal with the threat of a crime of honor. The innocence that she displays and that permeates her consciousness dismisses in the mind of the public and those related to her the prospect of illicit sexual behavior.

The fifth type I call the autonomous virgin. This woman is brainy, serious, and career-oriented. She has spent a great amount of time trying to prove to everybody, especially men, that she is both intelligent and competent. She is contemptuous of any sexual expression on the part of women, fearing that it would reinforce the idea that women are sexy dolls and empty-headed. She is formal and proper in her dealings with male colleagues, dresses very conservatively and wears no make-up. She avoids casual and non-substantive conversations with men. This woman is interested in attracting a marriage partner, but only through the traditional venue of the fam- 
ily. That is why she banks a great deal on a reputation for respectability. ${ }^{46}$

The autonomous virgin does not even consider approaching the dance floor, not out of contempt for the belly-dance but out of belief that the desegregation of the social space between men and women should only occur in the respectable institutions of the workplace and education. Erotic communication between the sexes is, to her, outrageous and ought to be banned. In many ways this woman is the traditional virgin who once lived in the segregated female space, but who is now wearing a business suit and going out to work or to get a degree. Though she shares with the virgin of love the contempt for sexual expression, she is similar to the sexy virgin in her refusal to engage in underground love and in seeking a marriage partner through the traditional means of the family. The autonomous virgin is not at risk of a crime of honor simply because she is one of its advocates. Believing in the propriety of honor ethics, she avoids to the best of her ability all kinds of shameless behavior. For her, honorableness in sexual conduct is a moral good.

The sixth character in my typology is the slut. This woman has the sexual history of the virgin of love. She is one who has engaged in underground sexual practices with one or two men she was madly in love with, but has since dropped the romantic consciousness associated with that type. Her underground life seems to have taught her two precious lessons: one concerning her own sexuality, the other concerning that of men. She has come to like, savor and appreciate sex; she had become nuanced and sophisticated in her understanding of her own sexuality. She has also come to know a great deal about men, shrugging off in the process her fear and apprehension of their sexual world. She is very much like the coquette, except that she is not married and is consciously out there to seduce a potential sexual partner. She is consciously sexy, seductive, and has a knack for sexual experimentation. Her shameless burgeoning sexuality blurs her concept of sexual ethics, unlike the sexy virgin (traditional ethics: sex within marriage), or the virgin of love (romantic ethics: sex with the loved one). She could be polygamous, involved with married men, other women, and so on. When this woman takes to the dance floor, she is as sexually sophisticated in her dance as the coquette, performing all the "right" moves and body gestures. She is often much more inviting in her dance than the coquette, utilizing to the best of her ability the erotic stuff that the belly-dance is made of. She is a very subversive element on the sexual landscape.

46. Women who work as civil servants best exemplify this kind of sexuality, along with professional women such as lawyers, engineers, doctors, and women who work in academia. 
The last type in my cast is the tease. This woman is an odd combination of the slut and the virgin. She shares with the slut her sexual savvy, but only through hearsay. This woman is sexually sophisticated, though she has not engaged in underground sex. She is usually upper-class and Westernized, which explains the richness and diversity of her sources of sexual knowledge (a temporary life in the West as a student, movies, books, magazines, parties). All this knowledge she uses to seduce, play and flirt with, and tease men. But like the sexy virgin, she insists on remaining a virgin, holding to the social wisdom that preserving her virginity will get her a good marriage and a reputation for respectability. She is hardly naïve or estranged from the world of men (and in that respect she departs radically from the sexy virgin). Her knowledge of the art of sexual seduction is sophisticated and learned. Her interaction with men is erotic, suggestive, inviting and playful. But it stops there. The exact opposite of the virgin of love, who obeys the public rituals of virginity but engages in underground sex, the tease behaves publicly like a slut but remains privately a virgin. She is the virgin slut who is attempting to be loyal to the last vestiges of virginity: the actual physical hymen.

The sexual types that I have explored above are ideal types. The same woman can shift from one to the other depending on the context, or display a combination of features associated with different varieties. Most women have a sexual history that covers more than one type. Women are not necessarily self-conscious about the type of sexuality they embody, and I suspect that many women would strongly resist my typology altogether, preferring to understand themselves in much more reductive and simplistic terms than the types allow.

Except for the coquette, the women embodying the above sexual types are unmarried. A very significant thing happens to Arab women when they marry: they almost always immediately become mothers. Motherhood seems to have a serious transformative effect on the different sexual types of women, so that, for instance, the narcissism of the sexy virgin is seriously curbed and she starts to develop a more careless disheveled look. The GAP girl loses her lithe girlish body and starts to look more like an older, asexual woman. Whereas the autonomous virgin sustains her asexuality through balancing her double burdens of working and motherhood, the virgin of love, usually upper-class, joins the cult of motherhood and drops all her girlish romantic baggage. ${ }^{47}$

47. For an excellent representation of the life of the sexy virgin turned virgin of love turned mother, see an interview with a Lebanese woman in SHAABAM, supra note 55 , at $116-22$. 


\section{A Sexual Typology of Arab Men under Nationalist Patriarchy}

In this section I offer a sexual typology of Arab men in the context of the nationalist social regime. When I refer to Arab men as virgins by default, I mean that the system of honor does not command them to be virginal; rather, it makes it very hard for them not to be. This, of course, is due to the inaccessibility of women, who are commanded to be virginal.

The first thing that should be acknowledged here is that, while being a virgin by command is different from being a virgin by default, the two have a great deal in common. Though the literature is rife with discussions of the virginity of Arab women, the virginity of Arab men is hardly mentioned. I need to stress this point because I believe that both men and women suffer under the yoke of virginity and the culture of honor, and that it is experienced as hardship by men no less than by women. Of course there is no threat to the life of the man if he violates the code of honor. However, that might not prove to be such a great consolation to him as he proceeds to negotiate his sexuality within the not-so-peaceful and often violent structure of honor.

In the traditional pre-nationalist context, a virgin by default engaged in all kinds of underground sexual practices that were socially accepted though not openly condoned. ${ }^{48}$ This man attained a great deal of his sexual pleasures on the streets (harassment), visiting prostitutes, watching belly-dancers, practicing homosexuality, and so on. And yet this same man was very much a virgin (in fact the majority of men seem to have been virgins when they were married), sharing with the female virgin certain aspects of (virginal) sexuality. These aspects include a sense of estrangement from the other sex, shyness and embarrassment in their presence. Arabic literature and cinema are full of stories of men who could not have sex with their newly wed wives on their wedding night, this being their first sexual experience conducted in the context of a hyped-up social celebration imposing great expectations on the man. ${ }^{49}$

Being a virgin by default included two other aspects that might, at first, look paradoxical. On the one hand, there was a strong predatory impulse. Seeing himself as deprived of sexual pleasures due to the fierce patriarchal fences that surround his objects of desire, this man behaved like a predator whose biggest challenge was to secretively break through those fences and obtain access to other men's women. The predator saw women as conquests he could congratulate himself on: as far as he was concerned they were hard-won victories.

48. For a brilliant literary representation of male sexuality in the traditional text, see RACHID BouJADRA, AL-INKAR (1969).

49. This is best captured in the Palestinian film,Wedding IN Gallees (Michael Khleifi, 1987). 
On the other hand, this man was also deeply interested in (and felt strongly about) preserving other women's virginity. It is not only that he had been terrorized into this position, though that might have been true, but that he very much felt that he had an investment in the institution of virginity. The virgin/whore dichotomy was something he strongly believed in. These contradictory impulses could conceivably have put him in a situation where, having with hard work attained access to his object of desire, he chose not to "blemish" her by having sex. In other words, he may very well have voluntarily chosen not to consummate his predatory project.

The desegregation of the gendered social space and the arrival of romantic love following the nationalist intervention created new sexual types of men who look like the natural "children" of the virgin by default. These types retain aspects of the sexuality of the virgin by default, but those aspects are now present in a looser and rather disintegrated way. They no longer coexist in a tight embrace producing only one type, the virgin by default., Rather, they have decoupled from their source of origin, each aspect producing a type in itself.

The most prevalent type in the nationalist social regime is that of the predator. ${ }^{50}$ This new predator looks very much like the old one. His life is a sexual pursuit of the new nationalist virgin (recall that according to the above analysis women are now ambivalently virginal as opposed to unequivocally so, as they were in the traditional context). However, the modern predator has a much more exciting life than his predecessor: his pool of potential conquests is infinitely bigger. This man is out actively pursuing virgins of love and also sexy virgins in the hope of turning them into virgins of love. He sweettalks them into joining him in some sort of underground sexual practice in the name of love, leading them to imagine this might ultimately take them to marriage. Life has never been so good for the predator; his list of conquests never so long. He seduces and runs away. He is charming, seductive, slick, and a great romance conversationalist.

Usually his success in seduction and predation makes him very suspicious of women and leery of their claim to an honorable sexual past. When this man marries, it is almost never out of love. He selects a sexy virgin or an autonomous virgin through the traditional venue of the family, imagining that he has secured a clean and safe woman who had no experience with sophisticated deceitful predators like himself. This man usually continues his predatory pursuits shortly after marriage.

The second type is the romantic virgin by default. This man is rather unconventional in Arab culture in that he insists on establish-

50. For an interesting discussion of the modern predator, see This Man I Reject, and the Reason: His Superficiality, HuRRIYYATI, Nov. 1, 1992. 
ing an intimate romantic relationship with the woman he intends to marry. He generally holds deep contempt for the predator, whom he sees as an abuser of women's feelings. For him, love and sex are intertwined and inseparable, whether as an underground practice or within the institution of marriage. At the same time, he entertains deep contempt for the traditional familiar ways of marriage, seeing them as backward. He varies in his attitude towards women's virginity. He could either feel strongly about his loved one's virginity, seeing it as a sign of her honorability, or be totally indifferent about it. His romanticism could push him to put his loved one on a pedestal, treating her as a romantic object of his fantasies rather than a sexual one. He could also choose to preserve his loved one's virginity out of a feeling of protection: he does not want to be the cause of her social damnation. Marriage is always the aim in the romantic life of this type of man as the natural culmination of his love.

This is the new "feminized" Arab man. The cultural production of this type of man is creating a kind of crisis in the social understanding of masculinity. He tends to be gentle, soft-spoken, and fastidious in his looks, clothes and haircut. The fact that he allows himself to be vulnerable to the agonies, anguish and yearnings of love challenges the macho image that a man should project: heartless, purposeful, conquering, and a triumphant survivor of the lures of women. Both he and the predator are narcissistic and conscious of their looks, except that the latter uses it for the purpose of his conquests, lending him the look of the new modern macho man. The narcissism of the romantic, on the other hand, makes him look more like a castrated man. ${ }^{51}$

It is important to point out that a great many men lead a sexual life balanced on the border between the predator and the romantic virgin by default. Though they see themselves as occasionally vulnerable to the woes of love, they nevertheless, for the most part, lead the life of the predator. They seize the opportunity for sexual practice whenever it presents itself, which would otherwise be difficult to attain given the fact that they are living in a world that is full of virgins. For them, predation is sexual opportunity.

The third type is the virginal virgin by default. This man is the heir of the virginal sexuality associated with the old traditional virgin by default. He is very much like a female virgin. His "proper" traditional upbringing made it difficult for him to pursue underground sexual practices, or any predatory behavior for that matter,

51. See Ghadah Samman, The Letters of Ghassan Kanafani to Ghadah Sam. MAN (1992). The publication of the love letters sent by the late Palestinian writer Kanafani to the Syrian writer Samman caused a furor in the Arab world among writers and non-writers alike. Kanafani, a much admired nationalist writer, came out in these letters as the "castrated" romantic who suffered greatly from Samman's rejection of his love; a shock to most of his faithful admirers. 
only to leave him in the uncomfortable position of being an absolute male virgin (that is, he has had no sexual experience with women whatsoever). As much as he might covet it, he finds himself, due to his virginal sexuality, simply unqualified to become either the predator or the romantic virgin by default.

Like a female virgin, he is shy, embarrassed and totally estranged from the world of the opposite sex. His intense discomfort in their presence and his sense of deep insecurity paralyze him and make it impossible for him to communicate erotically with women. He has neither the sense of comfort and ease that the romantic seems to have in the company of women, nor the self-confident conquering approach of the predator. This man senses himself unqualified for the new modern desegregated life of the nationalist text.

He shares with the old virgin by default the romantic culture of segregated love. He tends to suffer continuous crushes on women, most of whom he has never even spoken to. Love for him is a fantastic fixation on an object of desire that he experiences as unattainable. The predator and the romantic, sometimes his own friends, feel pity for him and continuously offer him advice on how to summon his courage and approach his object of fixation. This man entertains mixed feelings towards women. They are mysterious to him, confusing, puzzling, desirable, but equally feared. They frustrate him, and he feels hatred and resentment towards them for making him feel so helpless.

He resents the predator and the romantic, not only for their success with women, but because they make it increasingly difficult for the likes of him to approach women. Their existence is a reminder to him that women are "wooable" and, therefore, attainable, but only in accordance with rituals and practices that these men themselves have created: rituals that he feels incapable of enacting. He is ashamed to resort to the familial venue to procure him a wife (which he ultimately in desperation and frustrations does) because it is an indication to his more skilful peers that he has failed to romantically seduce a woman.

His resentment is further increased by the fact that he feels that women themselves are rather contemptuous of him for his sexual and social inadequacies. To them, he is not a particularly attractive man or type to be associated with: he is shy, immature, a child. Though they might be impressed with his propriety, they do not find that a particularly inviting trait.

The fourth type is the virgin by default tease. This man has inherited the traditional virgin by default's deep respect for women's virginity, a state he regards as necessary and before which he stands with a sense of awe that he cannot help. But he is neither virginal nor particularly romantic. In fact, he is quite predatory in his sexuality. 
Oddly and paradoxically enough, this man loves to attract women, and the more the better. He behaves very much like the predator: he dresses nicely, he is gentle, charming, slick and very seductive, and sweet-talks women into his trap. But he is not interested in enjoying the potential pleasures made accessible by his successful conquests, and in this he is different from the predator. Having gained the satisfaction of knowing that the woman has fallen into his trap (she is in love with him or interested in having an underground relationship), he swiftly disappears and refuses to pursue the sexual opportunities presented to him. He believes that women should be kept respectable and virginal, and that their willingness to have a relationship with him would inevitably tarnish them. The erotic pleasures of the tease are derived from his own acts of seduction and conquest, consisting merely of making women cling to and become attached to him.

This man is a predator manqué, with a sexuality that lies somewhere between that of the predator and that of the romantic. He could easily become a romantic because his interest in women's respectability makes him very susceptible to their feelings. In other words, women for him are not merely objects to be seduced as for the predator, they are also people with feelings, a view that he shares with the romantic. The tease might easily, therefore, fall in love with one of his conquests and end up marrying her. It is equally plausible, however, that he will use the traditional venue of the family to get for himself a sexy virgin, or an autonomous virgin, to marry.

The fifth character in my typology is the self-interested virgin by default. This man is a combination of the traditional virgin by default and the new nationalist one. On the one hand, he strongly believes that women should remain virginal, and he feels secure in a world where he is assured of this fact. Yet he feels seduced by the nationalist modern image of a man coupled with a woman who is educated, employed, in short, modern. In many ways, he is like the autonomous virgin in that he also approves of the desegregation of gendered space only in education and employment and not in the erotic sexual arena. His attraction to modernity also pushes him to participate in the culture of love because it is more modern.

The contradictory aspects of his sexuality (traditional and modern) are not particularly hard to reconcile. In the end he attains a modern "nationalist" marriage by falling in love with a socially and economically suitable sexy or autonomous virgin in his family: a cousin (near or distant), a neighbor, a daughter of friends of his family, a childhood companion. He usually chooses an educated, rather socially sophisticated, and perhaps even employed woman.

Having said all of that, I still assert that the desire for regular sex, rather than romance and love, is the primary reason that most Arab men resort to marriage. This is the case because virginity still 
survives strongly in Arab culture. The ambiguity that has befallen virginity made the sexual history of many Arab men much more diverse and complicated than that of their predecessors. But the ultimate need to resort to marriage as a means for obtaining frequent and easily accessed sex remains very important even today.

\section{Conclusion}

The existence of an underground sexuality, practiced by some of these new types, is a harbinger of the fact that the nationalist project of modernization may be running amok. These practices push men and, even more importantly, women in the direction of being more Westernized. In their underground behavior, they touch the tip of that evil that must at all costs be avoided-Western sexuality. This is why the various types are forms of resistance to nationalist patriarchy, even as they are, at the same time, products of it.

In this light, we can perhaps better understand the behavior of the Arab judiciary when it tolerates certain forms of traditional honor killings. This tolerance aims to preempt subversive sexual practices. Unless certain violence is unleashed against them, these practices will flourish beyond control and Arab society will slide into the dark pit of Western sexual life, something to be avoided at all cost. Far from attempting to reconstitute traditional society, these judges are simply interested in maintaining the precarious balance struck by the nationalists between tradition and modernity. The cases presented to these judges confront them directly with the inherent instability of a faltering system that needs to be supported. And we should acknowledge that the forms of resistance engaged in by the sexual types are themselves a response to the balance being struck between two types of violence, the private and the official.

\section{Afterword}

This Article is a revised version of a chapter in my S.J.D. thesis entitled, "Feminism, Nationalism and the Law in the Arab World," which I defended in 1993 . The chapter was very much a product of its time. Feminist discontent was the affective framework of its writing, and the combination of Critical Legal Studies analysis of law and post-structuralist thinking on gender were its tools of understanding. The legal and jurisprudential exposition of the paper was traced through the year 1985, close enough in time to be up to date when the chapter was written.

Signs of change in the social and political context described in that chapter were already looming on the horizon when I defended my thesis in 1993. While those changes added a new level of complexity, especially the emergence of new performances of virginity with 
the rise of Islamicization, they do not affect the main thrust of my argument here.

When I wrote my paper, crimes of honor were very much a "local" phenomenon, the concern of a handful, highly mobilized, feminist activists agitating in one Arab country or another. The rise in the 1990s of human rights as the new discourse of social activism, funded by foundations from elsewhere, turned crimes of honor into a "global" issue. By the end of that decade, one noted an upsurge in Englishlanguage publications on crimes of honor ${ }^{52}$ and a new type of activist: who does not necessarily consider herself a feminist and who is concerned about crimes of honor in the name of human rights. ${ }^{53}$ Because the emergence of human rights discourse on honor coincided with the increase of Islamicization, much of this discourse took pains to stress that honor crimes were not "Islamic." Note that my paper made no such attempt as it was located in a different time in history.

I should add that the globalization of honor crimes was also contemporaneous with the emergence of The Muslim Problem in Europe, as migrants from honor cultures came to assert their difference from European sexual culture in various ways, the occurrence of the honor crime in rare (though rising) occasions being one of them. ${ }^{54}$ Lacking a normative discourse on multiculturalism (it exists in the United States), and helpless in the face of the increased racism of its disenfranchised working class as a result of globalization, for which Muslims became a convenient object, Europe was quick to turn its legitimate aversion to honor crimes into illegitimate unbridled racism towards the "primitive Muslims." Thus, the crime of honor became a "European" problem.

The laws and judicial approaches I expounded in the paper are still in place in the Arab world to this day and the rate of crimes of honor remains roughly the same. It nevertheless behooves us to ask what influence the coupling of Islam and the market has had on the culture of honor. If, as I argued in my paper, honor had been nationalized in the modern nation states of the Arab world, coexisting with

52. For a compilation of literature written in English on crimes of honor from a human rights perspective, see http://www.soas.ac.uk/honourcrimes/bibliography/ file54988.pdf (last visited June 30, 2010).

53. See, for example, the Jordanian Journalist Rana Husseini who was catapulted into fame by the human rights industry by virtue of reporting on these crimes in a Jordanian newspaper published in English. Husseini published a book entitled, MURDER IN THE NAME OF HONOR, the main argument of which is that the crimes are "un-Islamic." See Husseini's website at: http://www.ranahusseini.com/ (last visited June 28, 2010). Husseini consistently asserts in her public lectures that she is not a "feminist."

54. For the rise of honor killings in Europe and the sense of urgency surrounding them among European state officials, see Europe Grapples with "Honor Killings," DeuTSChe WeLle (June 23, 2010), http://www.dw-world.de/dw/article/0,,1244406,00. html (last visited June 30,2010 ). 
its opposite, the concept of passion, the question is: in what way was honor Islamicized in the post-national modern state?

Of the three hymens, biological, physical, and spatial, the Islamic privileged the physical performance of virginity. Women flocked to adorn the Islamic dress to signal their moral purity. By privileging the physical hymen, the Islamic re-signified the biological and the spatial performances of virginity, making the physical synonymous with the other two. To wear the veil was to be a virgin in fact. To wear the veil was to be spatially segregated from men, the walls of the separation now redefined as the boundaries of the veiled body itself. This was even the case, in fact particularly so, when the veiled body moved in the midst (as it usually did) of desegregated gendered space. In other words, whereas the traditional era expanded the hymen from the biological to the spatial, the Islamic condensed its signification to that of the physical.

This is highly significant. Islamic discourse on the veil promised to do away with the anxiety typifying the performance of virginity in the nationalist era by recasting desegregation as its very opposite through the introduction of the Islamic dress. This "promise" of doing away with women's anxiety was a real one in a double and contradictory sense: the veil gave an easy and formal cover to both those who wanted to be virginal and befriend men, as well as to those who wanted to engage in sex while appearing respectable. It reduced the burdens of the former while giving cover to the latter. The veil proved of great service to both the sexy virgin and the virgin of love.

The coupling of the Islamic with the market, however, quickly undid its promise. One of the most interesting, and indeed rare, instances of local capital chasing away foreign imports is the Islamic dress fashion industry, which has emerged over the past two decades to meet the needs of an increasingly Islamic-dress-wearing female population. (I purposefully refer to it as Islamic-dress-wearing and not religious because, with the hegemony of Islamic dress, the signification "religious" lost its meaning. In its early moment as an embattled discourse, the Islamic dress signified the religiosity of its wearer. As it became "local dress," it could no longer signify religiosity nor act as its metonym.) The Islamic fashion dress industry proved innovative, turning itself into a local improviser of what the West seasonally produced in fashion. Quickly enough, sexiness flooded the Islamic through colored dress, tight dress, see-through dress, fashionable dress, etc. ${ }^{55}$ Yet another shift took place, corresponding this time with the Islamic becoming hegemonic, a further

55. For a discussion of the Islamic fashion industry in Egypt from within the field of "consumer studies," see Mona Abaza, Changing Consumer Cultures of Modern Egrpt: CaIro's Urban Reshaping (Social, Economic, and Political Studies of the Middle East and Asia, Series No. 101, 2006). 
displacement, condensation of the performance of virginity, now traversing the female body from one part to another: from the loosely covered body of the early times of Islamicization to the covered hair of hegemonic Islamicization. It was no longer the Islamic dress that signified virginity; it was the scarf in and of itself. Put differently, the hymen was now the woman's hair (as if pubic hair had traveled to the head), hidden, precious, the remaining sign of virginity. The ambiguities of the nationalist virginity script returned with full vengeance, and with it, the sexy virgin, virgin of love, autonomous virgin, and the slut. They are all now walking with a sexy (Islamic) dress and scarf trying to master the new and ambiguous script of Islamic virginity.

Nevertheless, the laws and jurisprudential approaches to honor killings I discussed in my paper are still in place. Despite the hegemony of Islam in culture, the secular (now post-) nationalists remain in control of the state in the Arab world (except in Iran). However, while state laws continue to do their distributive work on men's and women's sexualities supported by state sanctions, as described in the paper, there is another law in the shadow that is also doing its distributive work on those same sexualities, albeit without state sanctions (though it might seek such sanctions when the need arises).

The Islamist legislature sitting in the shadow (the "official" religious intelligentsia) -waiting to take over the state-addressing the issue of honor killings, finds itself producing differing opinions as to whether they are Islamic or not. While all strands in this parallel legislative body preach moral purity and strict abstention from sex before marriage, the liberal wing treats honor killings as decidedly contrary to Islam. It contends that, according to Islamic law, for sexual transgression to be punished, its actual commission must be proven according to the strict Islamic rules of evidence. Four witnesses have to be privy to the transgression or, alternatively, a willed confession has to issue from one of the perpetrators. As the killer for honor does away with these requirements, the killing is deemed in violation of Islamic law. It is a travesty, according to this wing, that national laws tolerate such killings. The conservative wing of the shadow Islamic legislature, on the other hand, finds basis for the killings in Islamic law arguing that this law excuses the man who finds himself in uncontrollable rage in the presence of his female relative's sexual transgression (provocation). It also argues that killing one who has transgressed, amounts to exercising the religious duty of "fending off sin."56

56. For a more elaborate exposition of Islamic law approaches to crimes of honor see Lama Abu Odeh, Crimes of Honor: Overview, in 2 ENCYClOPEDIA OF WOMEN \& IsLAMic Cultures 221 (Suad Joseph ed., 2005). 
To make matters worse, while both of these "official" wings, although disagreeing over the merits of honor killing, advocate abstention from sex before marriagewhat constitutes marriage in the first place has itself become controversial. The secular national state had regulated marriage closely, requiring the presence of an official from the state in the marriage ceremony and a complex set of registration procedures. No sooner had the modern state succeeded in abolishing marital practices taking place outside its purview (which it had attributed to distant rural populations yet to be incorporated into the new state institutions) than it found itself confronting the new sexualized urban religious youth begging to differ (with the state and with their own official intelligentsia). Finding support in the informal fatwas of their ethereal muftis, these youths argued that marriage needs not be registered by the state and that it may very well be based on an oral contract between a man and a woman. New forms of "marital practices" took to the fore confusing the "official" prohibition against "sex before marriage." The irony, of course, is that the Islamic parallel/shadow state found itself confronting its own parallel/shadow one.

We may be witnessing in the shadow of the shadow state of Islam a new avant-garde of religious youths who, in its pursuit of a new marriage (sex), is laying the foundation for a permissive way to have sex before marriage and in this manner destabilize the very foundation of honor culture itself. It may very well be that in order to dishonor honor, the way to go is not to preach sexual emancipation ( $a$ la West) or passionate love (as I do), but to simply redefine marriage, diversify its practices, and reclassify its occurrence ... and these young religious ones might be on to something! 